\title{
The Emam Zadeh Chahar Rustayi Site, a Bakun Period Settlement in Bushehr Province, Southern Iran
}

\author{
Hakimeh Bargahi ${ }^{1}$, Mohammad Hossein Rezaei ${ }^{2, *}$ \\ ${ }^{1}$ Archaeology Department, Central Tehran Campus, Islamic Azad University \\ ${ }^{2}$ Archaeology Department, Neyshabur University \\ *Corresponding Author: mohammad.1561@yahoo.com
}

Copyright (C) 2015 Horizon Research Publishing All rights reserved.

\begin{abstract}
Genaveh County is located on the NE coast of the Persian Gulf with an area of about 1837 Square kilometers, 165 kilometers Northwest of Bushehr. Our information about the prehistoric period of the coastal province of Bushehr is very limited. The few studies conducted in this area have not been systematic and have not pursued a specific goal. Only for the Paleolithic period has some research been done. Therefore, our systematic study in this region has attempted to identify the cultural status of this area. The Chahar Rustayi archaeological site $\left(34^{\circ} 68^{\prime} 47^{\prime \prime} \mathrm{N}\right.$; $57^{\circ} 69^{\prime} 32^{\prime \prime} \mathrm{E}$; 87-meter elevation) is located within 5 kilometers of the west bank of the Shoor River and 2 kilometers south of the village of Chahar Rustayi. Realizing the importance of the Chahar Rustayi site (Eman Zadeh Hill or Tepe Emam Zadeh) to the understanding of regional exchanges, and the utility of pottery in identifying prehistoric cultures, as well as the role of pottery shapes and designs in assigning the sequence of cultural eras, our goal was a thorough analysis of the cultural materials obtained in a methodical study of the site to clarify the cultural succession of the region. After mapping and $10 \times 10 \mathrm{~m}^{2}$ gridding of the area, alternative sampling was performed on $50 \%$ of the squares (207 squares). Pottery and lithic material recovered during the surface survey showed that this site had been settled from the late Neolithic Period until the end of Chalcolithic Period.
\end{abstract}

Keywords Iranian Prehistory, Systematic Survey, Pottery, Bakun Period, Chahar Rustayi Site, Chalcolithic

\section{Introduction}

The Province of Bushehr, with an area of 23167 square kilometers, is located in the southern part of Iran (centered around $28^{\circ} 58^{\prime} \mathrm{N} 50^{\circ} 50^{\prime} \mathrm{E}$ ) on the eastern margin of the Persian Gulf. It has an average altitude of about 5 meters, and is bordered on the north by Khuzestan, Kohgiluyeh, and Boyer-Ahmad provinces, in the east by Fars Province, and in the southeast and southwest by Hormozgan Province (Figure

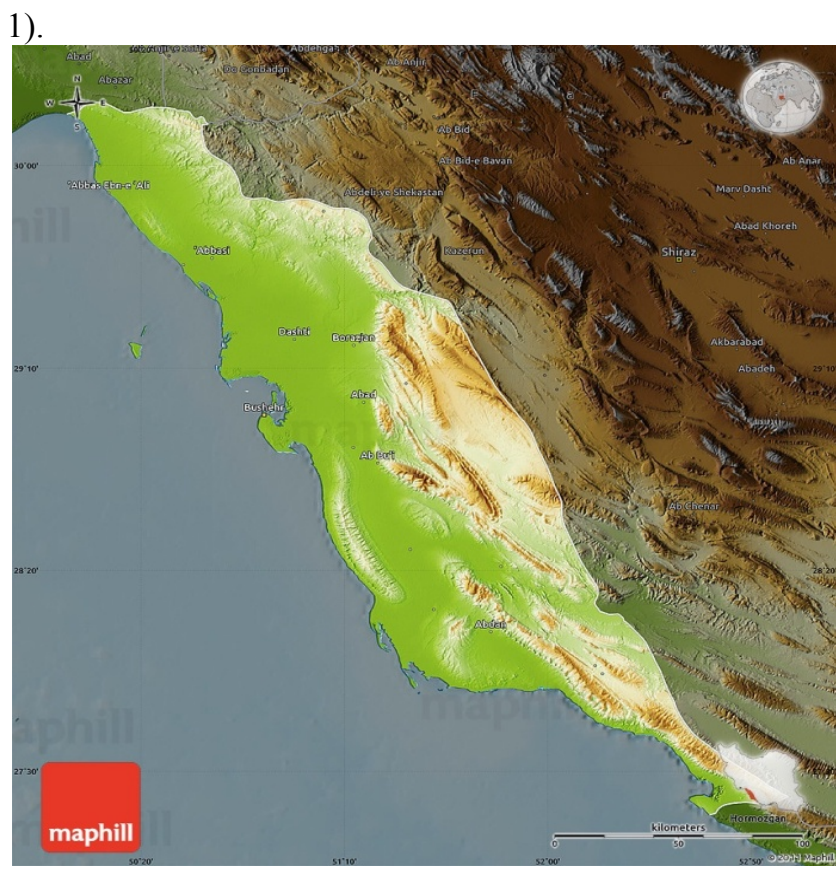

Figure 1. Location of Bushehr Province

The Chahar Rustayi site lies at $34^{\circ} 68^{\prime} 47^{\prime \prime} \mathrm{N} 57^{\circ} 69^{\prime} 32^{\prime \prime} \mathrm{E}$ at 87- meters elevation, and is located less than 5 kilometers west of the Shoor River, and 2 kilometers from the village of Chahar Rustayi [1]. The Chahar Rustyi Site was first identified and recorded in 2004 during an archaeological survey along the shores of the Persian Gulf conducted by an Iranian-English team supervised by Robert Carter [2]

Eman Zadeh Hill is a low relatively large hill with a flat surface approximately 270 meters long, 148 meters wide, and 4 meters high. The vestige of a gravel road, 1.50 meters long and 1 meter high composed of sand and grit, is clearly visible on the central part of the hill's surface. A trench has been dug around the hill by the Natural Resources Organization to delimit the hill from the surrounding lands, and trees have been planted on the entire surface of the hill. A dirt road, which runs towards the nearby Amir el Momenin Shrine has cut through and destroyed the central part of the site, divides it into eastern and western parts. (Figure 3). 


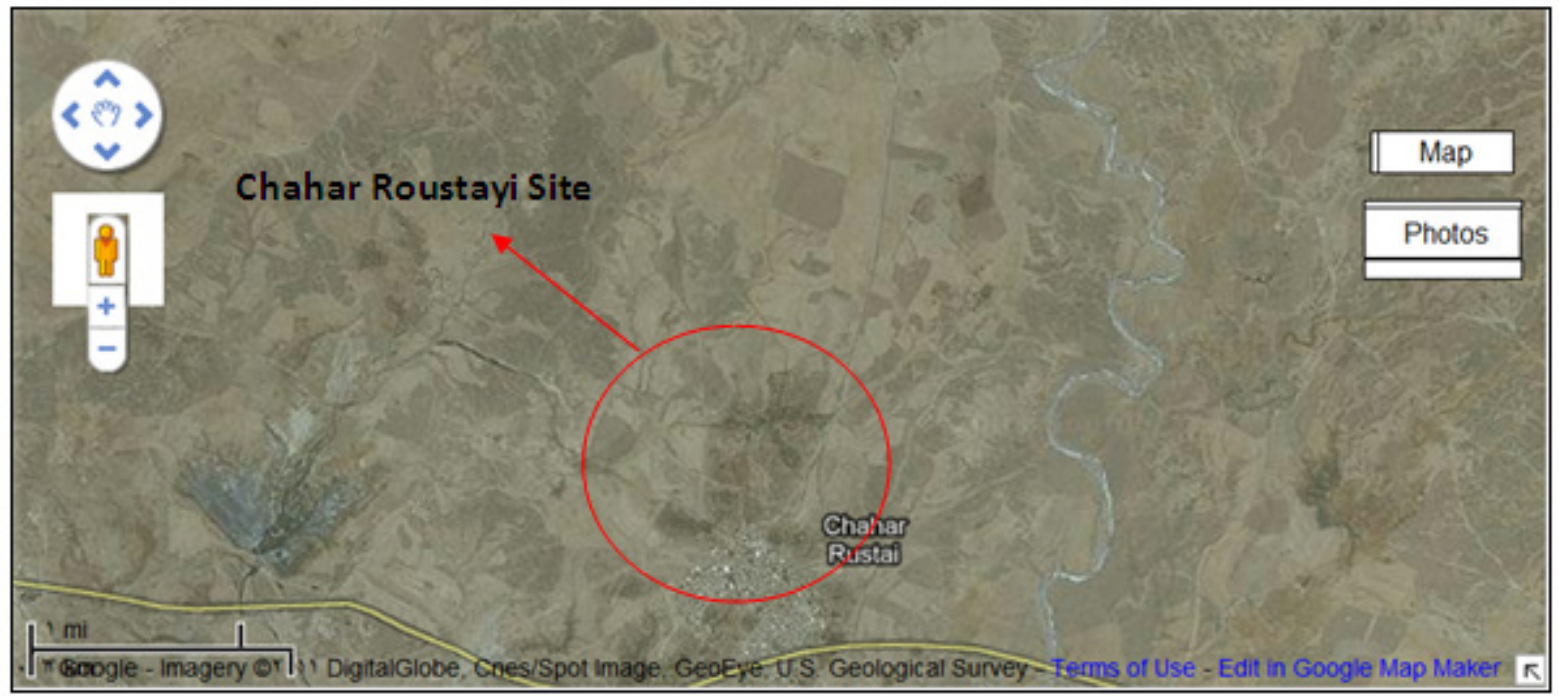

Figure 2. Location of Chahar Roustayi Site

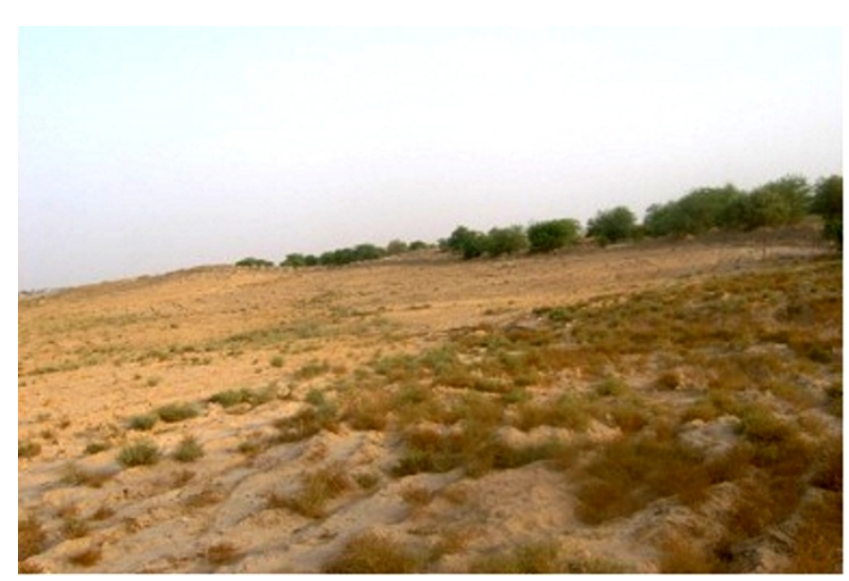

Figure 3. Chahar Roustayi Site

The Shoor Kolahi River is the best water resource for the site, and is lies about 4.5 kilometers west of the hill. There is also a small ephemeral wetland on the eastern margin of the site which still contains water and is a sanctuary for animals and birds, especially migratory birds, but is dry by summer. This wetland was probably part of an earlier channel of the Shoor River, but was eventually cut off from the river, becoming a habitat for birds.

Investigstion of Tepe Emam Zadeh was conducted using a systematic survey method. The primary goal was to achieve an understanding of the relationship between Tepe Emam Zadeh and other sites located in southern and southwestern Iran. Our intention was to prepare a chronological table, and present the resulting data as a framework for the implementation of future long-term, systematic excavations in this area.

\section{Methodology}

\section{Mapping}

Topographic mapping of the Chahar Rustayi Site, began with selection of the highest point of the hill and its designation as point $\mathrm{A}$. Then, using a GPS instrument and a string balance, the elevations and angles were recorded for determining the coordinates. To the south and within 10 meters of point $\mathrm{A}$, another point was designated as B, and the north-south axis of the hill was determined along these points. The grid network was formed into four sections using string. The northwestern, southwestern, northeastern and southeastern quadrants were respectively gridded. First, the northwestern quadrant was divided into $10 \times 10 \mathrm{~m}^{2}$ squares using a string and wooden pegs. Then the squares were named. For naming the squares, vertical/west sides of the grid were assigned numbers, and the horizontal/north sides of the grid were assigned letters. On the numbered side, the northern most row of squares was numbered 1 , and the western most row of the squares was designated with A (see Figure 4)

\section{Sampling}

Sampling began in square A1 and ended in square Q21. The collected samples were placed in plastic bags bearing labels including square name, date and name of the person in charge, and for greater certainty, a card with similar information was placed into the bag.

A total of 414 squares in $10 \times 10 \mathrm{~m}^{2}$ dimensions were created on the surface of the hill (Table 1). Due to lack of time and money, the vertical rows were sampled alternately, that is, only $50 \%$ of the squares were sampled. Out of 207 sampled squares, 122 squares contained nothing (that is, there were no movable objects to be evaluated and collected from the square). Out of a total of 191 samples, there were 170 pottery sherds and 21 lithic fragments. 


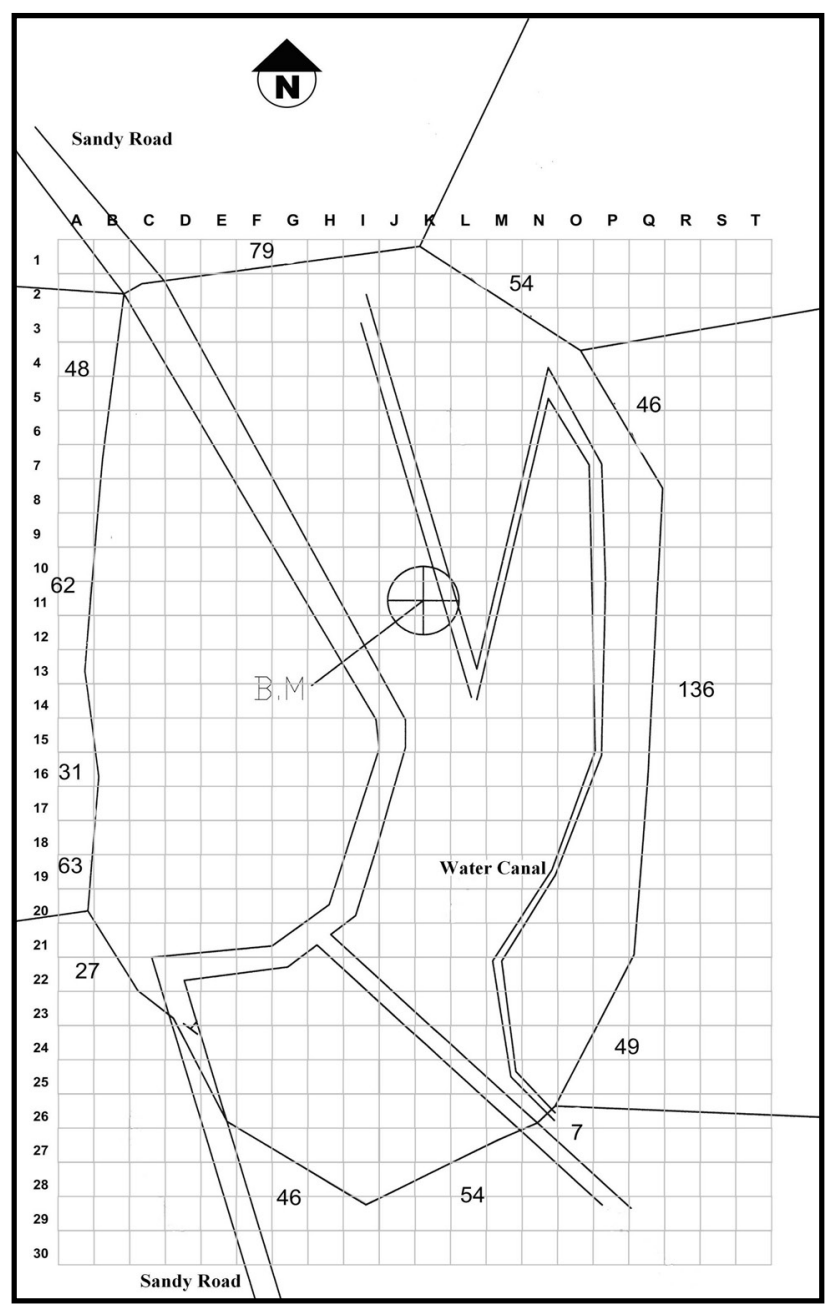

Figure 4. topography of Chahar Rustayi Site

Table 1. Gridding of the systematic archaeological survey of the Chahar Rustayi Site.

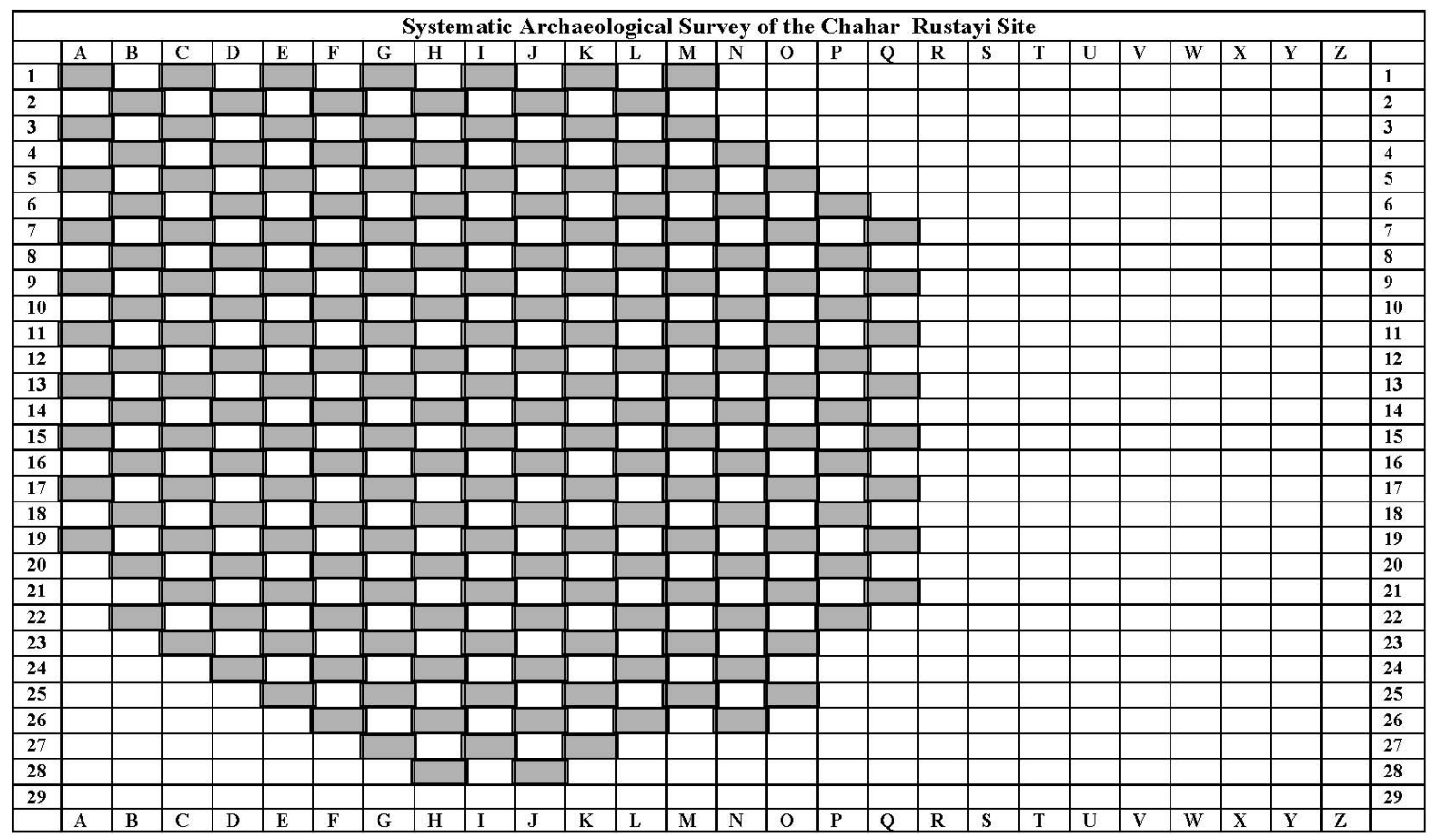




\section{Discussion}

Pottery sherd frequency is plotted in the pie chart below (Figure 5). Most of the identified sherds were of the Bakun B2 period. The frequency of the pottery was as follows: the lowest number was of the Bakun B1 period with 4 sherds, equivalent to 2 percent of the pottery recovered; Bakun B2 period pottery with 143 sherds comprised 88 percent of the total sherd; Bakun A type pottery with 10 sherds, was equivalent to $6 \%$ of the total sherds; Finally Lapui period pottery with 6 sherds, comprised 4 percent of the total identified sherds (Figure 5).

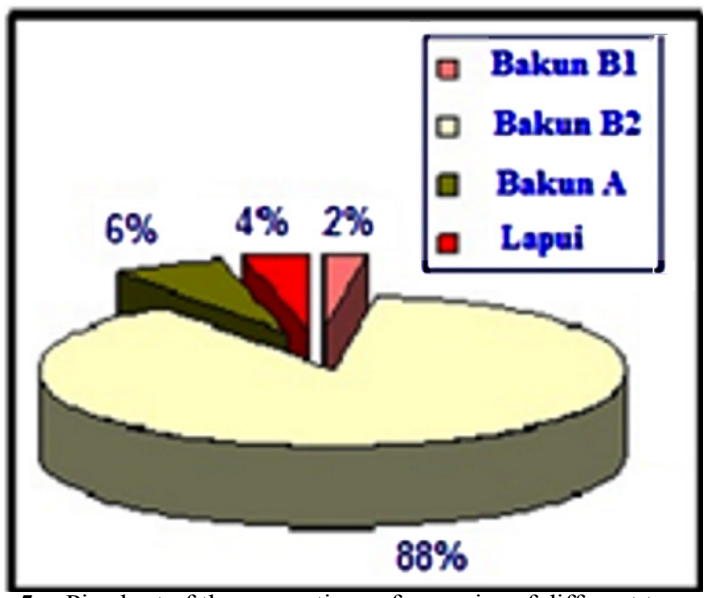

Figure 5. Pie chart of the proportions of ceramics of different types recovered during the survey of the Chahar Roustayi Site.

After separation of pottery based upon morphology (rim, body, base shapes), they were subject to typology based on decoration (Figures 6, 7, 8). Among these sherds, a major part was comprised of portions of the body. Pottery is the most important archaeological tool in the Middle East, and because it was the major artifact recovered during the archaeological survey of Chahar Rustayi Emam Zadeh Hill, its analyses forms the basis for the chronology, and regional comparisons of the site (Figure 10). In this analysis, due to lack of stratified prehistoric sites in Bushehr, pottery from the site was compared with those excavated from sites in Fars and Khuzestan provinces, e.g., from Tale Bakun, Tale gap, Tale Nurabad, Choghamish and Choghabanut (Table 2).

Comparison of pottery from the Chahar Rustayi Site with the prehistoric pottery of other cultural zones of southern and southwestern Iran showed that the pottery of the Chahar Rustayi Site is very similar to samples from Fars Province to the east, in particular from the Marvdasht Plain and Mamasani region (Fig.1) Only in that region, have pottery designs comparable to those recovered from the Chahar Rustayi Site been found. Therefore, this suggests a close relationship between the Genaveh region with Marvdasht and the Nurabad plains. Although the form and design of Chahar Rustayi Site pottery is similar to the form of pottery in southern and southwestern Iran, what makes them more similar to more local pottery is the flexibility or angular form of the designs (perhaps a question of taste). Also there are differences in more technical issues such as size, temper amount, and pottery color. In a comparison of designs of the pottery from the Chahar Rustayi Site with those of Tale Bakun and Tale Nurabad in Fars, it is seems that only geometric designs (mostly crossed hatchings, diamond hatchings and broad bands) can be seen, and no example of plant, animal and human motifs were found.

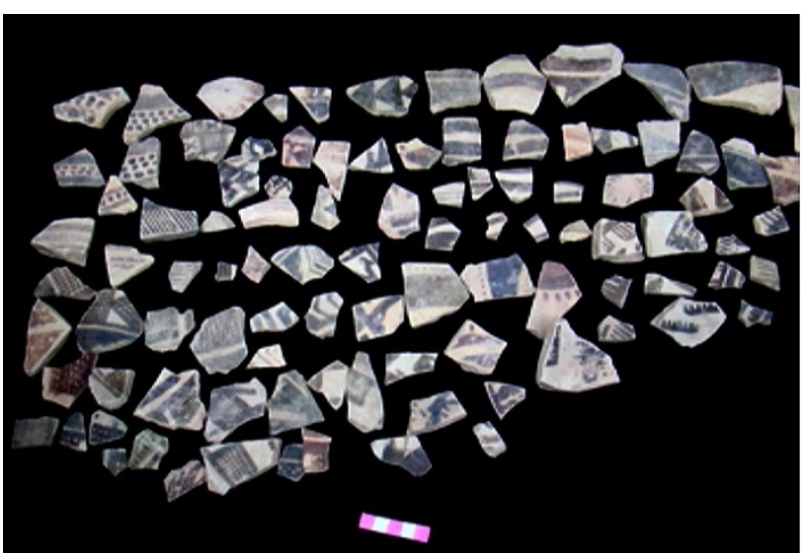

Figure 6. Body sherds

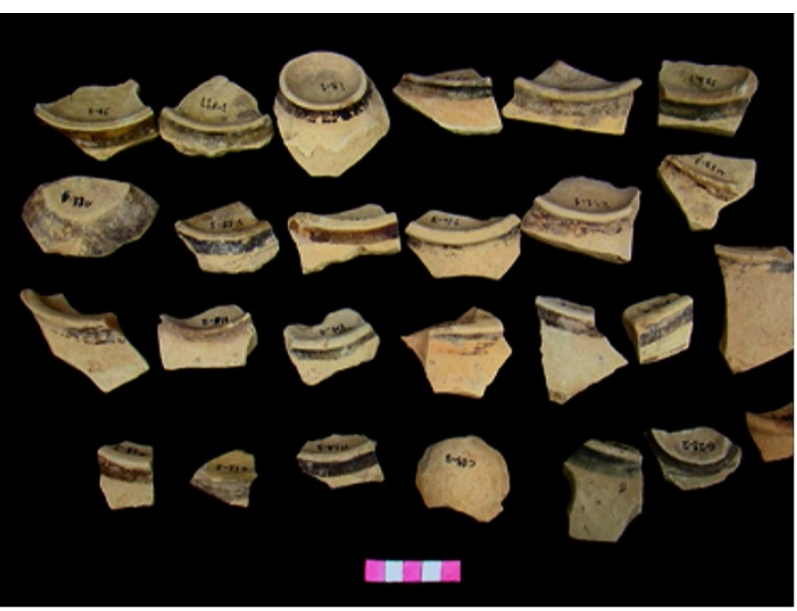

Figure 7. Base sherds

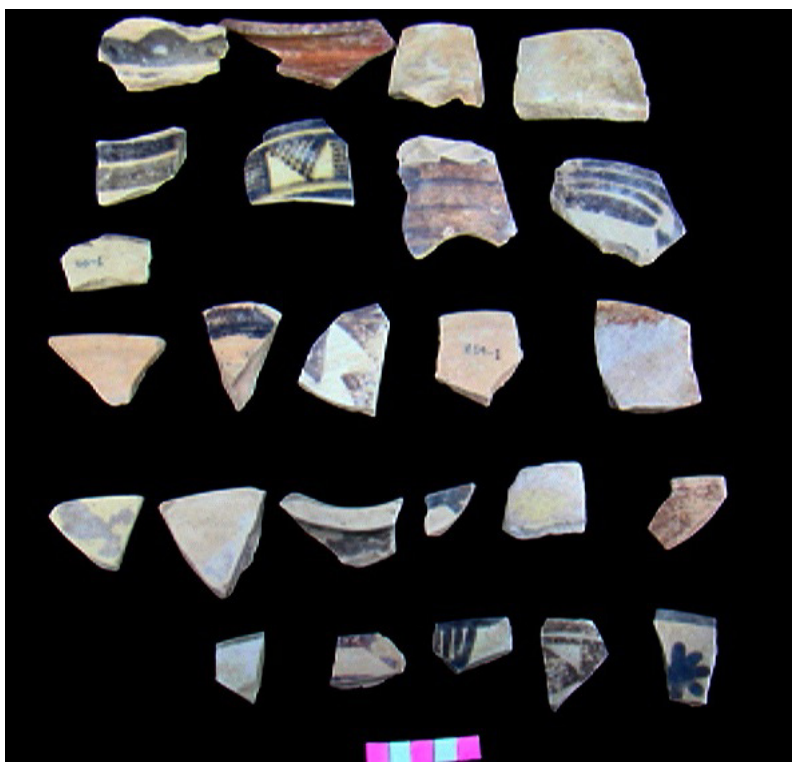

Figure 8. Rim sherds 
Table 2. Descriptions of pottery from other areas

\begin{tabular}{|c|c|c|c|c|c|c|c|c|c|c|c|c|}
\hline Extra-local comparison references & $\begin{array}{c}\text { Chronology }= \\
\text { probable period }\end{array}$ & Temper & $\begin{array}{c}\text { Inside } \\
\text { color slip }\end{array}$ & $\begin{array}{c}\text { Surface } \\
\text { color }\end{array}$ & $\begin{array}{l}\text { Fabric } \\
\text { (core) }\end{array}$ & Decoration & Firing & Quality & Technique & $\begin{array}{c}\text { Square } \\
\text { number }\end{array}$ & $\begin{array}{c}\text { Sherd } \\
\text { type }\end{array}$ & Number \\
\hline $\begin{array}{l}\text { Egami \& Sono } 1962 \text { figs.12.5-6-15.10, } 28.4 \text { [3]; } \\
\text { Egami \& Massuda } 1962 \text { fig.15.11 [4]; Egami et al } 1977 \\
\text { pl.III.19 [5]; Lagsdorff \& McCown 1942 pl 9.1-6 [6]; } \\
\text { Delougaz \& Kantor 1996 XIVC-2.118 [7]; Hole \& } \\
\text { Flannery } 1969 \text { fig. 52, j-f-I [8] }\end{array}$ & Bakun B2 & vegetal & buff light & $\begin{array}{l}\text { buff } \\
\text { light }\end{array}$ & buff & $\begin{array}{l}\text { painted } \\
\text { black } \\
\text { duplex }\end{array}$ & well & fine & wheel & M7-3 & rim & 1 \\
\hline Alizadeh $2004 \quad 77,78$ fig: 22,E fig. 35 D [9] & Bakun B2 & vegetal & buff light & $\begin{array}{l}\text { buff } \\
\text { light }\end{array}$ & buff & $\begin{array}{r}\text { painted } \\
\text { brown } \\
\text { duplex }\end{array}$ & well & fine & wheel & G8-4 & rim & 2 \\
\hline $\begin{array}{l}\text { Alizadeh } 2008 \text { fig: VIII-3, } 187 \text { [10] Pots \& Roustaei } \\
2006 \text { fig. 3.87, tnp } 1204 \text { [11] }\end{array}$ & Bakun B2 & vegetal & buff light & $\begin{array}{l}\text { buff } \\
\text { light }\end{array}$ & buff & $\begin{array}{c}\text { painted } \\
\text { black }\end{array}$ & well & fine & wheel & $\mathrm{C} 1-1$ & body & 3 \\
\hline $\begin{array}{l}\text { Delougaz \& Kantor } 1996 \text { [7] } \\
\text { Pots \& Roustaei } 2006 \text { fig. 3.55tnp1317 [11] } \\
\text { Hole \& Flannery } 1969 \text { fig. 52, e, f [8] Carter \& Challis } \\
2004 \text { fig. bh. 56, } 36 \text { [2] }\end{array}$ & Bakun B2 & vegetal & buff light & $\begin{array}{l}\text { buff } \\
\text { light }\end{array}$ & buff & $\begin{array}{l}\text { painted } \\
\text { black }\end{array}$ & well & fine & wheel & $\mathrm{N} 14-2$ & body & 4 \\
\hline $\begin{array}{l}\text { Carter \& Challis } 2004 \text { fig. bh. 56, 44, } 142 \text { [2] } \\
\text { Pots \& Roustaei } 2006 \text { fig. 3.86tnp1204 [11] }\end{array}$ & Bakun B2 & vegetal & buff light & $\begin{array}{l}\text { buff } \\
\text { light }\end{array}$ & buff & $\begin{array}{c}\text { painted } \\
\text { black \& } \\
\text { brown }\end{array}$ & well & fine & wheel & H16-1 & body & 5 \\
\hline $\begin{array}{l}\text { Carter \& Challis } 2004 \text { fig. bh56.142.30 [2] } \\
\text { Pots \& Roustaei } 2006 \text { fig 3.82tnp1355 [11] }\end{array}$ & Bakun B2 & vegetal & buff light & $\begin{array}{l}\text { buff } \\
\text { light }\end{array}$ & buff & $\begin{array}{l}\text { painted } \\
\text { black }\end{array}$ & well & fine & wheel & A7-2 & body & 6 \\
\hline $\begin{array}{l}\text { Carter \& Challis } 2004 \text { fig. bh 56 3, } 44.231 \text { [2] } \\
\text { Pots \& Roustaei } 2006 \text { fig. 3.91tnp1055 [11] }\end{array}$ & Bakun B2 & vegetal & buff light & $\begin{array}{l}\text { buff } \\
\text { light }\end{array}$ & buff & $\begin{array}{l}\text { painted } \\
\text { black }\end{array}$ & well & fine & wheel & $\mathrm{C} 17-1$ & body & 7 \\
\hline $\begin{array}{l}\text { Carter \& Challis } 2004 \text { fig. bh56, 35, } 142 \text { [2] } \\
\text { Pots \& Roustaei } 2006 \text { fig. 3.87tnp1194 } \\
\text { Alizadeh } 2008 \text { fig. } 4 \text {, f [10] }\end{array}$ & Bakun B2 & vegetal & buff light & $\begin{array}{l}\text { buff } \\
\text { light }\end{array}$ & buff & $\begin{array}{c}\text { painted } \\
\text { black }\end{array}$ & well & fine & wheel & G11-4 & body & 8 \\
\hline Pots \& Roustaei 2006 fig: 4.115, TS1407 [11] & Lapui & vegetal & buff light & $\begin{array}{l}\text { buff } \\
\text { light }\end{array}$ & red & $\begin{array}{l}\text { painted } \\
\text { black }\end{array}$ & well & fine & wheel & B6-4 & body & 9 \\
\hline $\begin{array}{l}\text { Pots \& Roustaei } 2006 \text { fig. } 4.96 \mathrm{Ts} 501,567 \text { [11] } \\
\text { Miroschedji 1981a fig. 26,9 [12] } \\
\text { Carter \& Challis 2004 fig. bh56.19.140 [2] }\end{array}$ & Bakun B2 & vegetal & red & $\begin{array}{l}\text { buff } \\
\text { light }\end{array}$ & red & $\begin{array}{c}\text { painted } \\
\text { black }\end{array}$ & well & fine & wheel & I13-3 & base & 10 \\
\hline $\begin{array}{l}\text { Carter \& Challis } 2004 \text { fig. bh56,17 [2] Pots \& Roustaei } \\
2006 \text { fig. 3.82, tnp1325 [11] }\end{array}$ & Bakun B2 & vegetal & buff light & $\begin{array}{l}\text { buff } \\
\text { light }\end{array}$ & buff & $\begin{array}{l}\text { painted } \\
\text { black } \\
\text { duplex }\end{array}$ & well & fine & wheel & H6-2 & base & 11 \\
\hline $\begin{array}{l}\text { Deluogaz and Kantor } 1996 \text { pl.176 r.192.c [7] } \\
\text { Langsdorff \& McCown } 1942 \text { pl.5.9,10 [6] }\end{array}$ & Bakun B2 & vegetal & buff light & $\begin{array}{l}\text { buff } \\
\text { light }\end{array}$ & buff & $\begin{array}{l}\text { painted } \\
\text { black } \\
\text { duplex }\end{array}$ & well & $\begin{array}{c}\text { mediu } \\
\mathrm{m}\end{array}$ & wheel & L16-1 & base & 12 \\
\hline Carter \& Challis 2004 fig. bh56 .76 [2] & Bakun B2 & vegetal & buff light & $\begin{array}{l}\text { buff } \\
\text { light }\end{array}$ & buff & $\begin{array}{l}\text { painted } \\
\text { black } \\
\text { duplex }\end{array}$ & well & fine & wheel & B10-3 & base & 13 \\
\hline
\end{tabular}


Table 3. Pottery distribution at the Chahar Roustayi Site by period: Bakun B1 (yellow), Bakun B2 (Black), Bakun A (Blue), and Lapui (Red)

\begin{tabular}{|l|l|l|l|l|l|l|l|l|l|l|l|l|l|l|l|l|l|l|l|l|l|l|l|l|l|}
\hline \multicolumn{2}{|c|}{ Systematic Archaelogical Survey of the Chahar Rustayi Site } \\
\hline
\end{tabular}

The density and frequency of finds in the central and southern parts of the hill was higher than in other parts. The most dense concentration of artifacts ( 15 pieces) was found in square F20 in the southern part of the hill. Evaluating the spatial distribution of dated pottery indicated the density and frequency of Bakun B1 pottery is greatest on the northern part of the hill, although the greatest number of sherds of this period were retrieved from square A9 (2 samples) located on the southern part of the hill. The greatest density and abundance of Bakun B2 pottery shereds was on the southern and central parts of the hill. The greatest number of sherds of this period was found in square F20 (15 sherds) located on the southern part of the hill. Bakun A pottery sherds were often found as interspersed with sherds of other ages. The greatest number of sherds of this period was recovered in square F8 (three sherds). There were a few sherds of Lapui period pottery. Most of these sherds were scattered, primarily on the northern and central parts of the hill. The greatest number of sherds of this period were retrieved from square $\mathrm{J} 20$ (two sherds) located in the southwestern part of the hill (Table 3 ).

The lithics recovered from the surface of the site included retouched blades, a notched bladelet, a notched flake, a rejuvenation core bladelet, and an end scraper on bladelet (Figure 10).

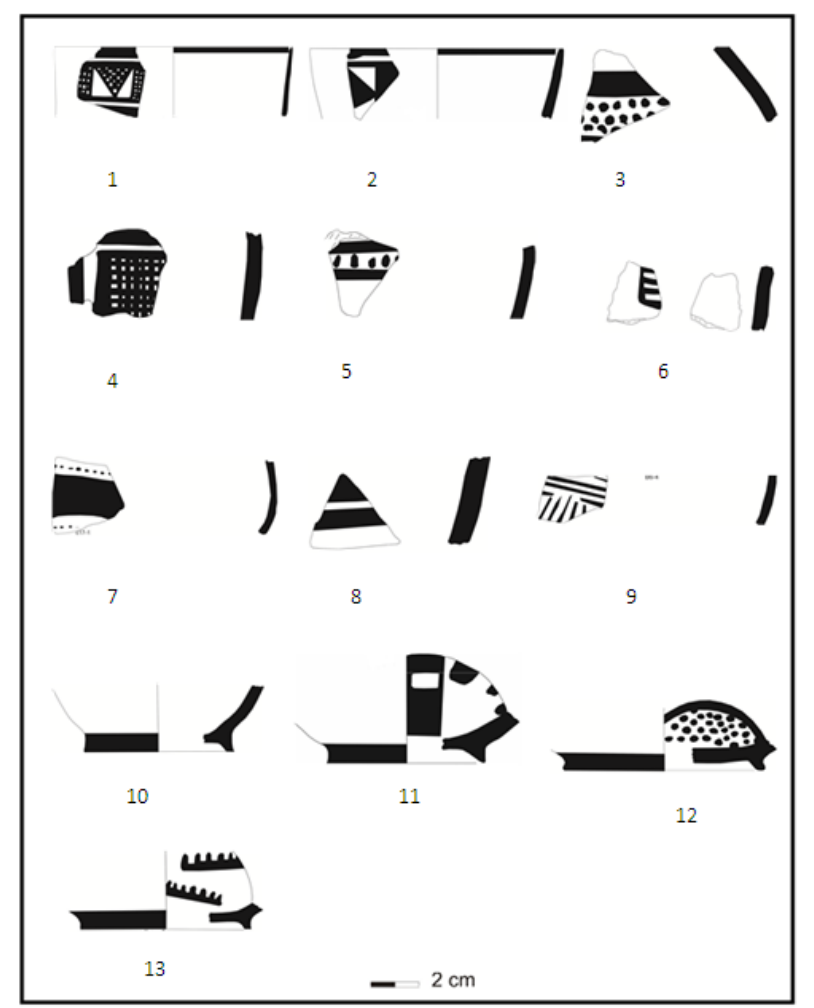

Figure 9. Sketch of painted designs on sherds from the Chahar Roustayi Site 


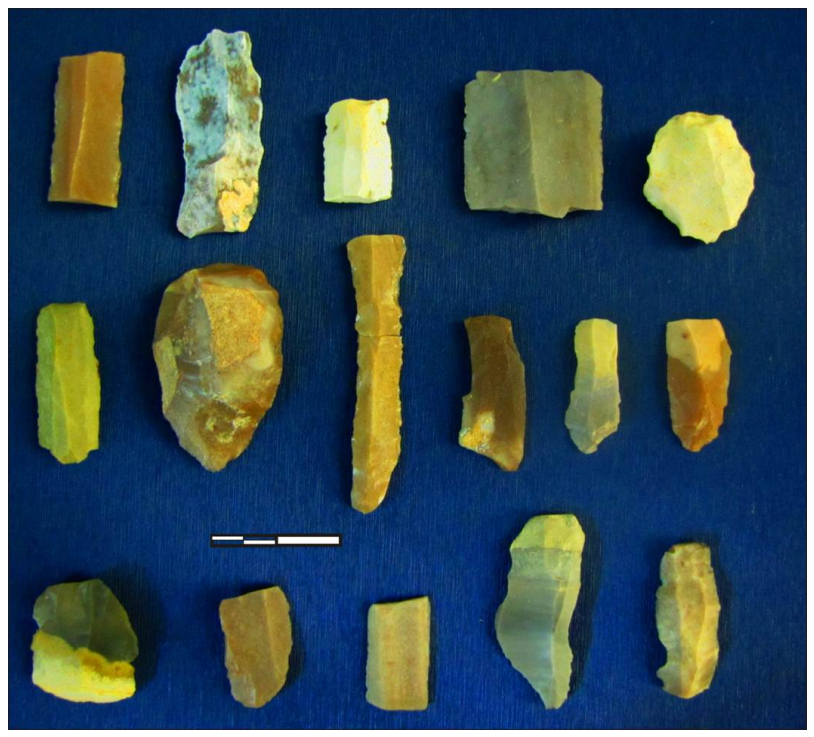

Figure 10. Lithics (the scale is 2 centimeters)

\section{Conclusions}

The pottery and lithics recovered during a systematic surface survey of the Chahar Rustayi Site indicates that it has been inhabited from the early fifth millennium B.C. until the late fourth millennium B.C. When the Chahar Rustayi Site pottery is compared with stratified sites in Fars, it clearly has been settled from the end of Neolithic Period (contemporary with Bakun B1-type pottery) up to the late Chalcolithic Period (contemporary with Lapui-type pottery) according to the chronology.

The presence of the hollow pottery with plant temper and buff color along with lithics, including chipped stone, bladelet, scraper, etc. indicates settlement of this site beginning during the Neolithic period. Distribution of the pottery indicates that most of the settlements of the various periods were primarily in the central and southern parts of the hill. Based upon the distribution of pottery sherds, it seems that this site had its greatest extent during the Early Chalcolithic (Bakun B2) Period. The majority of the sherds found $(88 \%)$ are from this period. Comparison of the pottery designs of the Chahar Rustayi Site with other sites in south and southwestern Iran indicate that this site has had an intra-regional relationship with other sites of Bushehr Province, and has had extensive extra-regional relations with the Tale Bakun, Tale Nurabad, Choghamish hill and Chaghabanut hill regions in the Fars and Khuzestan provinces [11]; [7]; [2]; [3]; [9]; [6].

Finally, it is necessary to point out, that, so far, the description of the prehistoric settlement of the Chahar Rustayi Site only relies on evidence obtained from surface survey, and upon a limited number of pottery sherds that compare favorably with those from regions primarily to the west of Bushehr Province. In the final analysis, a more reliable interpretation should be based upon the far more accurate results of extensive, radiocarbon-dated, stratigraphic excavations of the site.

\section{REFERENCES}

[1] Gramimotlagh and Shabankareyi, M. 2006. Bushehr climatic zones, Scientific and research Journal of Isfahan University, Vol.20, No. 1, p 210.

[2] Carter, R.A, Challis, K., Priestman, S.M.N. \& Tofighian, H. 2006: 'The Bushehr Hinterland. Results of the First Season of the Iranian-British Archaeological Survey of Bushehr Province, November-December 2004', Iran, 44: 63-103.

[3] Egami, N. and Sono, T. 1962. Marv-Dasht II: The Excavation at Tall-i-Gap 1959. Tokyo University Iraq-Iran Archaeological Expedition Reports, 3, Institute of Oriental Culture of the University of Tokyo, Tokyo.

[4] Egami, N. and Masuda, S. 1962. Marv-Dasht I: The Excavation at Tal-i-Bakun 1956. Tokyo University Iraq-Iran Archaeological Expedition Reports, 2, Institute of Oriental Culture of the University of Tokyo, Tokyo.

[5] Egami, N., Masuda, S. and Gotoh, T. 1977. "Tal-i Jarri A: A preliminary report of the excavations in Marv Dasht, 1961 and 1971", Orient 8: 1-14.

[6] Langsdorff, A. and McCown, D. E. 1942. Tall-i-Bakun A: Season of 1932. Oriental Institute Publications, LIX, University of Chicago Press, Chicago.

[7] Delougaz, P. and Kantor, H. J., (Eds.), 1996, Chogha Mish Volume 1: The First Five Seasons of Excavations 1961-1971, Oriental Institute Publications 101, Oriental Institute, Chicago.

[8] Hole, F., Flannery, K.V., and Neely, J. 1969. Prehistory and Human Ecology of the Deh Luran Plain. An Early Village Sequence from Khuzistan, Iran. Memoirs of the Museum of Anthropology 1. Ann Arbor: University of Michigan

[9] Alizadeh, A., 2004. The basis of governmental institutions in prehistoric Fars. First edition, translated by K. Roostayi, Parseh research foundation.

[10] Alizadeh, A., 2008, Choghamish II, the development of prehistoric regional center in lowland Susiana, southwestern Iran, final report on the last six seasons of excavation (1972-1978), the Oriental Institute of the University of Chicago. Oriental Institute Publication, Volume 130, Chicago. Illinois.

[11] Potts, D. T. and K. Roustaei (eds.). 2006. The Mamasani archaeological project stage one: A report on the first two seasons of the ICAR-University of Sydney Expedition to the Mamasani District, Fars Province, Iran, pp. 1-16. Tehran: Iranian Center for Archaeological Research.

[12] De Miroshedji, P. 1987. Fouilles du chantier Ville Royale IIà Suse (1975-1977). II. - Niveaux d'époques achéménide, parthe et islamique, Cahiers de la DAFI 15. Pp. 11-143. 